\title{
HARMONISASI SOSIAL BUDAYA ANTAR UMAT BERAGAMA DI DESA LOLIBUKECAMATAN LAKUDO KABUPATEN BUTON TENGAH
}

\author{
${ }^{1}$ Muliyono, ${ }^{2}$ La Taena, dan ${ }^{3 *}$ La Aso \\ Program Studi Kajian Budaya Pascasarjana, Universitas Halu Oleo, Kendari \\ Jurusan Pendidikan Ekonomi, Fakultas Keguruan dan Ilmu Pendidikan, \\ Universitas Halu Oleo, Kendari \\ Jurusan Bahasa dan Sastra, Fakultas Budaya Universitas Halu Oleo, Kendari
}

\section{Corresponding Author: *La Aso (la_aso@yahoo.co.id)}

\begin{abstract}
Abstrak: Keberagaman budaya di Indonesiamerupakan anugrah dari Allah termasuk perbedaan agama. Perbedaan ini terkadang menjadi pemicu terjadinya konflik ditengah masyarakat, sepertikonflik Poso, Ambon, Wamena dan lain lain. Akan tetapi tidak semua daerah yang berbeda selalu terjadi konflik bahkan sebaliknya terlihat aman, damai, harmonis. Tujuan penelitian ini adalah untuk menganalisis dan mendeskrisipkan harmonisasi interaksi sosial budaya dan sebab-seba terjadinya intereaksi sosial budaya umat beragama di Desa Lolibu. Teori untuk membaca data adalah pemikiran Max Webber (1992), tentang interaksi sosial.Metode yang digunakan dalam penelitian ini adalah deskriptif kualitatif, dimana data diperoleh melalui observasi dan wawancara, serta melakukan pengamatan hal-halyang terkait dengan interaksi sosial budaya umat beragama. Hasil penelitian ini menunjukkan bahwa intereaksi sosial budaya antara umat beragama di Desa Lolibu, dapat di uraikan sebagai berikut: (1) Harmonisasi interaksi sosial budaya antar umat beragama terjadi karena: (a)adanya ikatan wilayah,(b) saling menghormati dan menghargai antar penganut agama, dan (c) harmonisasi birokrasi Desa Lolibu, (2) Faktor-faktor penyebab terjadinya interaksi sosial budaya antara umat beragama adalah disebabkan: (a) adanya satuan adat dan budaya, (b) adanya gotong royong (Pohamba-hambai), dan (c) adanya kawin mawin antar warga desa Lolibu.
\end{abstract}

\section{Kata Kunci: Harmonisasi, umat, beragama, desa Lolibu}

Abstract: Cultural diversity in Indonesia is a gift from Allah, including religious differences. This difference sometimes triggers conflicts in the community, such as conflict in Poso, Ambon, Wamena and others conflicts in Indonesia. However, not all different regions always have conflicts. On the contrary, they are safe, peaceful, and harmonious. The objective of this research was to analyze and describe the harmonization of socio-cultural interactions and the causes of the socio-cultural interactions of religious communities in Lolibu Village. The theory for reading data is the thought of Max Webber (1992), about social interaction. The method used in this research is descriptive qualitative, in which the data were obtained through observation and interviews, as well as observing matters related to religious sociocultural interactions. The results of this research showed that the socio-cultural interactions between religious communities in Lolibu Village can be described as follows: (1) Harmonization of socio-cultural interactions between religious 
communities occurs because: (a) the existence of regional ties, (b) mutual respect and respect among religious adherents, and (c) the harmonization of the Lolibu Village bureaucracy, (2) The factors that cause the culture socio interactions between religious communities are due to: (a) the existence of a customary and cultural unit, (b) the existence of mutual cooperation (pohamba-hambai), and (c) the existence of marriage system between the community of Lolibu village.

\section{Keywords: Harmonization, community, religion, Lolibu village}

\section{PENDAHULUAN}

Secara fitrah manusia membutuhkan interaksi sosial untuk menjalin hubungan yang baik antar manusia. Agama merupakan unsur yang sangat penting di dalamnya.Salah satu fungsi dari agama adalah memupuk rasa persaudaraan. Berdasarkan penjelasan dan keputusan Presiden No 1 Tahun 1965 bahwa, agama-agama yang dipeluk penduduk bangsa Indonesia adalah Agama Islam, Kristen Katolik, Kristen Protestan, Budha, Hindu, dan Kung $\mathrm{Hu}$ Chu. Adanya jaminan dalam memeluk agama bagi tiap-tiap warga Negara dan diakuinya enam agama resmi membuat masyarakat Indonesia yang bertempat tinggal dalam suatu daerah tidak dalam satu keyakinan. Salah satu fungsi agama adalah memupuk rasa persaudaraan. Kendati fungsi tersebut telah dibuktikan dengan fakta-fakta yang konkrit dari zaman ke zaman.Namun dari fakta-fakta yang positif itu terdapat pula fakta yang negatif yang ditimbulkan oleh agama.

Edelman (dalam Munajat, 2018) peristiwa disharmonis menimbulkan berbagai dampak seperti terjadinya keretakan hubungan antar individu atau kelompok, adanya perubahan kepribadian seseorang seperti memunculkan rasa benci yang dapat menjadi tindak kekerasan, hancurnya harta benda dan korban jiwa, kemiskinan bertambah akibat tidak kondusifnya keamanan, lumpuhnya roda perekonomian hingga rusaknya fasilitas pendidikan formal dan informal. Trauma psikologis juga menjadi dampak yang dirasakan korban peristiwa disharmonis, trauma psikologis dapat menjadi watak disharmonis dengan hidup penuh kecurigaan, tidak ada kenyamanan, ketentraman, dan menjadi dendam ketika mereka harus berhadapan dengan etnis yang telah menyebabkan mereka menderita sepanjang hidup mereka (Haudy, 2001).

Seperti pada peristiwa disharmonis Poso pada tahun 1998-2001 yang telah membuat semua orang mulai dari perempuan, laki-laki, orangtua, remaja, anak-anak, dan lanjut usia mengalami trauma karena dipaksa masuk dalam pusaran situasi disharmonis dengan kekerasan berdarah yang berkepanjangan (Gogali, 2009).

Peristiwa disharmonis Situbondo yang terjadi pada tahun 1996 telah berdampak pada rusaknya beberapa infrastruktur seperti 23 buah tempat ibadahRusak, 6 lembaga pendidikan, 1 panti sosial, 1 perkantoran, dan 7 sarana publik (Carmin, 2018).

Penelitian menunjukan bahwa Desa Lolibu merupakan salah satu desa yang ada di Kabupaten Buton Tengah, yang mana masyarakatnya terdapat dua pemeluk agama. Kehidupan antara Masyarakat Katolik dengan Masyarakat Islam di Desa Lolibu terlihat sangat harmonis. Diperkirakan terdapat faktorfaktor yang menyebabkan terjadinya harmonisasi, yang dikembangkan oleh masyarakat Desa Lolibu dalam menjaga keharmonisan hidup mereka. Belum 
banyak penelitian yang dilakukan untuk mengetahui faktor apa yang menjadi kunci terjadinya harmonisasi tersebut dan faktor-faktor apa yang telah dikembangkan untuk menjaganya. Sehingga penelitian ini dilakukan untuk mengisi kekosongan atau menambah kejelasan tentang faktor-faktor penyebab terjadinya harmonisasi dalam pluralitas agama serta strategi yang dikembangkan dalam menjaga keharmonisan hidup mereka. Untuk selanjutnya dapat dijadikan model replikasi di tempat lain yang rawan dengan konflik sara.

Dengan hal itu, berdasarkan hasil penelitian terkait adanya harmonisasi sosial budaya antar umat beragama di Desa Lolibu pemulis menemukan ada beberapa faktor sampai harmonis. Adapun keharmonisan yang dimaksud adalah: adanya ikatan wilayah,saling menghormati dan menghargai antar penganut agama, harmonisasi birokrasi Desa Lolibu. Kemudian ada pun faktorfaktor penyebab terjadinya harmonisasi antar umat beragama di Desa Lolibu yaitu: satuan adat dan budaya, Gotong royong (Pohamba-hambai), dan kawin mawin.

Harmonisasi antara umat beragama bukanhal baru dalam kajian ilmu pengetahuan, banyak hasil penelitian yang mengkaji hal ini. Adapun beberapa hasil penelitian terkait tentang harmonisasi sosial budaya antar umat beragama adalah sebagai berikut: Imam Sujarwanto (2012) dalam penelitiannya yang berjudul "Interaksi Sosial Antar Umat Beragama (Studi Kasus Pada Masyarakat Karangmalang Kedung banteng KabupatenTegal" Peneleitianya bertujuan untuk mengetahui proses sosial dalam interaksi sosial umat Hindu dan umat Islam. Metode yang digunakan dalam penelitiannya adalah studi interaksi sosial. Hasil menunjukkan bahwa proses sosial interaksi yang umum ditemukan adalah gotong royong dan tolong menolong, akomodasi melalui toleransi, dan asimilasi.Faktorfaktor yang mendorong terjalinnya interaksi sosial budaya kejawen,kerabat dan faktor ekonomi, sedangkan faktor penghambat interaksi sosial adalah komunikasi, masalah mayoritas dan minoritas. Faktor yang mempengaruhi pola interaksi adalah faktor budaya dan faktor ekonomi. Saluran efektif yang membangun interaksi sosial adalah upacara keagamaan, upacara inisiasi, kegiatan sosial budaya.Saran dalam penelitian ini adalah pola-pola Interaksi sosial yang sudah berjalan dengan baik terus dipertahankan, bentuk stigma minoritas perlu dihilangkan, dan saluransaluran kominikasi yang menghambat perlu dibuka, dengan secara terusmenerus melakukan berbagai kominkasi dalam menghadapi persoalan. Kesimpulan Bentuk interaksi sosial antara Umat Hindudan Islam dalam masyarakat Karang malang adalah kerjasama kerukunan yang termasuk di dalamnya adalah gotong royong (kerigan) dan tolong-menolong (sambatan). Akomodasi yang pada titik tertentu memerlukan kehadiran pemimpin seperti kyai, pandhita maupun kepala desa. Sedangkan asimilasi yang bekerja adalah toleransi di antara pemeluk Hindu dan Islam. Sikap toleransi dilandasi oleh nilai-nilai budaya dasar yang mementingkan keserasian hidup bersama.

Akbar (2017) dalam penelitiannya yang berjudul Interaksi Antar Umat Beragama Studi Kasus Islam-Kristen Di Kecamatan Sukakarya Kota Sabang. Penelitiannya bertujuan untuk mengetahui Pola interaksi yang terbangun pada Masyarakat Sukakarya metode analisis data bersifat deskriptif 
analisis. Hasil penelitian menunjukkan bahwa bentuk interkasi sosial antar Muslim dan Kristendi Kecamatan Sukakarya mengarah pada proses yang asosiatif, dimana didapati adanya pola hubungaan membaur antar masyarakatnya, yang ditandai adanya kerjasama, akomodasi dan asimilasi pada pola interkasi masyarakatnya. Meskipun demikian, juga didapati adanya potensi yang mengarah pada bentuk interaksi yang disosiatif seperti ketegangan dan konflik namun dapat ditutupi dengan adanya peran pemerintah gampong dan kota dalam membina hungan antar pemeluk agama yang rukun dan harmonis. Lebih lanjut, diketahui bahwa faktor terjadinya interaksi sosial antar Muslim dan Kristen yaitu adanya gotong royong, ikatan kekeluargaan dan saling menghormati dan menghargai antar umat beragama. Kesimpulannya bahwa Kecamatan Sukakarya merupakan salah satu dari dua kecamatan yang adadi kota Sabang, dengan komposisi masyarakat yang heterogen, dimana masyakatnya hidup dalam sebuah perbedaan, dan jauh dari keteganganketegangan justru masyarakatnya hidup dalam keadaan rukun dan harmonis. Kondisi seperti ini terwujud karena proses interaksi sosial yang terjadi dalam masyarakat mengarah pada proses-proses yang asosiatif. Seperti dijumpai adanya kerjasama (kooperatif) yang ditandai adanya gotong royong dan tolong-menolong antar sesama masyarakat tanpa memandang status agama dan suku seperti yang terjadi antara warga muslim dan Kristen. Bentuk akomodasi yang ditandai dengan adanya keseimbangan dalam masyarakat, seperti pola hubungan masyarakat yang membaur dan sikap masyarakatnya yang toleran terhadap perbedaan agama dan suku. Selanjutnya adanya usaha-usaha untuk mencapai kestabilan, seperti peran pemerintah Gampong dalam mewujudkan kestabilan hubungan masyarakat beda agama.Selanjutnya asimilasi berupa usaha- usaha menumbuh-kembangkan kesatuan tindak dan sikap seperti sikap muslim dan Kristen yang toleran, saling menghormati dalam perbedaan dan sikap tolong menolong.

Ubad Badru Salam (2017) dalam penelitiannya yang berjudul Interaksi Sosial Antar Umat Beragama Di Kecamatan Sukmajaya Depok (Studi atas Pandangan Tokoh Agama Islam dan Kristen). Tujuan untuk memberikan pemahaman kepada pembaca bagaimana okoh Agama Kecamatan Sukmajaya Depok dalam mangartikan dan memahami tentang interaksi sosial antar umat beragama dan untuk mengetahui informasi yang dapat meluruskan pandangan dan membangun sikap yang benar sesuai dengan norma-norma interaksi yang ada.Sehingga dalam kegiatan hidup bermasyarakat baik bertetangga, mitra kerja di perkantoran atau teman seprofesi tidak menimbulkan keraguan mana yang boleh dikerjakan dan mana yang tidak boleh dikerjakan, tanpa menghilangkan rasa persaudaraan dan persahabatan diantara mereka yang berbada keyakinan.metode penelitian kualitatif menurut Sugiyono ialah metode yang digunakan untuk meneliti kondisi objek yang alamiah, dimana peneliti adalah sebagai instrumen kunci, teknik pengumpulam data dilakukan secara trianggulasi yaitu gabungan dokumentasi pustaka atau fotografi, wawancara dan observasi lapangan. Analisa data bersifat induktif dan hasil penelitian kualitatif lebih menekankan makna dari pada generalisasiHasilnya 
bahwa ada batasan-batasan dalam Islam tentang pembolehan dan pelarangan proses interaksi dengan non muslim dalam segala ranah, baik ranah akidah (pengucapan selamat hari raya, salam, pembangunan rumah ibadah) dan sosial (ekonomi, pendidikan). Dengan kesadaran diri penulis menpelajari aspek-aspek khusus (akidah) dalam islam maupun kristen melalui bacaan ataupun wawancara dengan para tokoh. Dapat disimpulkan bahwa sesungguhnya semua agama mengajarkan kepada umatnya kebaikan, kebajikan, kebenaran dan menghormati ajaran-ajaran dari agama lain. Dari semua itu bertujuan kepada amal ibadah kita kepada Tuhan.Dalam hal menghormati ajaran agama sebagai makhluk sosial hendaknya memahami aturan-aturan sosial yang ada dimana dia tinggal. Interaksi dipandang oleh para tokoh agama di Kecamatan Sukmajaya adalah sebagai wadah terbesar dalam menjalin hubungan toleransi hidup beragama. Sudah menjadi kebiasaan sebagaian besar warga kecamatan Sukmajaya membuat bingkisan paskah atau idul fitri dan bingkisan, hal itu biasa mereka bagikan kepada masyarakat sekitar, ini sudah menjadi kebiasaan yang di warsikan para orangtua terdahulu dan masih dipertahankan hingga saat ini, karena hal ini dapat menjadi pererat antar masyarakat kecamatan Sukmajaya.

Rini Fidiyani (2006:69) dalam penelitiannya yang berjudul Kerukunan Umat Beragama Di Indonesia Belajar Keharomonisan dan Toleransi Umat Beragama Di Desa Cikakak, Kec. Wangon, Kab. Banyumas. Penelitian ini merupakan penelitian kualitatif dengan metode pendekatan dari antropologi, etnografi dan hukum. Hasil penelitian, kearifan lokal yang ada pada Komunitas Aboge juga tidak lepas dari nilai-nilai kebudayaan Jawa, seperti saling menghargai (toleransi), menghargai perbedaan, penghargaan dan penghormatan pada roh lelulur, kebersamaan yang diwujudkan dalam kegiatan kerjan bakti / gotong royong, tulus ikhlas, cinta damai, tidak diskriminasi, terbuka terhadap nilai-nilai dariluar dan konsisten. Tidak ada perbedaan mencolok antara Islam Aboge dengan Islam lainnya, hanya perhitungan penanggalan yang berbeda dan ini menjadi simbol formal bagi mereka.Tidak adapembinaan kerohanian atau keagamaan dari instansi terkait. Instansi tersebut hanya memberi perhatian terhadap desa tersebut yang berpotensi menjadi objek wisata.Perlu ada langkah yang serius untuk melestarikan kearifan lokal komunitas Islam Aboge agar tetap lestari. Kesimpulannya bahwa yang dapat diberikan adalah sebagai berikut. Pertama, Islam Aboge merupakan bentuk akulturasi Islam dan budaya Jawa yang dapat dilihat dari situs dan ritus yang ada di Desa Cikakak. Bentuk kearifan lokal yang ada pada Komunitas Aboge juga tidak lepas dari nilai-nilai kebudayaan Jawa, seperti saling menghargai (toleransi), menghargai perbedaan, penghargaan dan penghormatanpada roh lelulur, kebersamaan yang diwujudkan dalam kegiatan kerja bakti/gotong royong, tulusikhlas, cinta damai, tidak diskriminasi, terbuka terhadap nilai-nilai dari luar dan konsisten. Kedua, ajaran pada Islam Aboge apabila dilihat dari tiga pendekatan teologi adalah sebagai berikut.Pada umumnya mereka tidak berbeda dengan Islam secara umum dalam halkitab suci, nabi, rukun Islam, rukun Imam, dansebagainya.

A. Markarma (2014) dalam judul penelitianya Pola Interaksi Berbasis 
Agama Pada Masyarakat Rawan Konflik di Kabupaten Sigi. Adapun tujuan dari pada penelitian ini adalah untuk menganalisis Pola Interaksi Berbasis Agama Pada Masyarakat Rawan Konflik di Kabupaten Sigi dan untuk menganalisis implikasinya terhadap upaya mengatasi konflik sosial di Kabupaten Sigi. Adapun metode yang ia pakai dalam peneltian ini adalah kualitatif. Hasilnya dari penelitan ini adalah Pertama: Pola interaksi berbasis agama pada masyarakat rawan konflik di Kabupaten Sigi, tidak berjalan efektif. Hal ini disebabkan karena pemahaman agama masyarakat pada wilayah tersebut berkaitan dengan nilai-nilai kebersamaan yang diajarkan oleh agama sangat minim. Konsikuwensinya adalah kesadaran dan sikap beragama masyarakat "menyimpang" dari ajaran agama itu sendiri.Jalinan interaksi sosial masyarakat hanya bersifat hubungan biasa dan tidak didasari oleh pemahaman agama yang baik. Kondisi ini membuat hubungan sosial yang dibangun mudah putus, ketika terjadi gesekan-gesekan kepentingan dalam masyarakat. Secara faktual, mayoritas masyarakat yang terlibat dalam konflik sosial atau perkelahian antar kelompok, memang tidak memahami nilai-nilai kebersamaan yang diajarkan agama; Kedua: Implikasi pola interaksi berbasis agama terhadap upaya mengatasi konflik sosial di Kabupaten Sigi, tidak signifikan. Interkasi sosial berbasis agama pada masyarakat rawan konflik tidak melahirkan pola hidup bersama untuk mencapai kehidupan yang harmonis dan saling menghormati Jalinan interaksi sosial yang terjadi kemudian tidak dinamis dan tidak mempunyai pola tertentu yangdapat diikuti oleh semua elemen masyarakat. Benturan-benturan kepentingan yang terjadi pada masyarakat rawan konflik tersebut, kemudian memicu konflik sosial yang "mentradisi" karena sudah melibatkan semua elemen masyarakat dari semua tingkatan umur. Dampaknya adalah volume konflik sosial sangat tinggi dan sulit diatasi, akan tetapi pola interaksi berbasis agama minimal dapat mempersempit potensi konflik sosial yang ada. Kesimpulannya Pola interaksi berbasis agama pada masyarakat rawan konflik di Kabupaten Sigi, tidak berjalan efektif. Hal ini disebabkan karena pemahaman agama masyarakat pada wilayah tersebut berkaitan dengan nilainilai kebersamaan yang diajarkan oleh agama sangat minim.Konsikuwensinya adalah kesadaran dan sikap beragama masyarakat "menyimpang" dari ajaran agama itu sendiri.Jalinan interaksi sosial masyarakat hanya bersifat hubungan biasa dan tidak didasari oleh pemahaman agama yang baik.Kondisi ini membuat hubungan sosial yang dibangun mudah putus, ketika terjadi gesekan-gesekan kepentingan dalam masyarakat.

\section{METODE PENELITIAN}

\section{Lokasi Penelitian}

Penelitian ini dilaksanakan di Desa Lolibu, Kecamatan Lakudo, Kabupaten Buton Tengah. Pemilihan lokasi ini dengan pertimbangan bahwa Desa Lolibu merupakan salah satu daerah yang memiliki keunikan tersendiri yakni keberagaman agama dan hidup rukun, hal ini ditandai dengan adanya harmonis sosial budaya mereka.

\section{Penentuan Informan}

Penentuan informan dalam penelitian ini adalah menggunakan Purposive Sampling, yaitu pemilihan informan berdasarkan kebutuhan penulis atau pemilihan informan secara sengaja. Hal tersebut mengacu pada Spradley 
(1997) mengatakan bahwa seorang informan sebaiknya mereka yang mengetahui dan memahami secara tepat permasalahan penelitian, sehingga diperoleh informasi sebanyak mungkin dalam rangka menjawab permasalahan penelitian.

Berdasarkan hal di atas bahwa informan yang dipilih terdiri atas informan kunci dan informan biasa. Informan kunci dalam penelitian ini adalah Pemerintah Desa Lolibu beserta tokoh Agama dan tokoh Adat yang dianggap mampu memberikan informasi terkait permasalahan penelitian, adapun informan kunci yang telah di wawancarai di antaranya sebagai berikut: (1) La Tamusi (90 tahun) ia sebagai tokoh Adat, (2) La Samba (96 tahun), ia sebagai tokoh Adat, Syahrun (34 tahun) ia sebagai Kepala Desa Lolibu, (5) La Ada (65 tahun) ia sebagai Imam Desa Lolibu , (6) La Mania (52 tahun) ia sebagia tokoh agama Kristen, (7) Rahmat (44 tahun) ia sebagai sekretaris Desa Lolibu. Sedangkan informan biasa, yaitu terdiri dari pemerintah desa, tokoh masyarakat, tokoh pemuda dan masyarakat biasa yang dianggap mampu dapat memberikan informasi yang berkaitan dengan permasalahan penelitian. Adapun informan biasa yang perna di Wawancarai yakni sebagai berkut: (1) Ramli (55 tahun) ia sebagai tokoh masyarakat, (2) Jasman (31 tahun) ia sebagai Bendarah Desa, (3) Filipus Misi (42 tahun) ia sebagai Kepala Kampung, (4) Anton (34 tahun) ia sebagai masyarakat Desa, (5) Rahim Adam (39) ia sebagai Kepala Seksi Pemerintahan.

\section{Jenis dan Sumber Data}

Jenis data dalam penelitian ini, yaitu data kualitatif yang berupa uraian yang dianalisiskan dan data kuantitatif yang berupa angka-angka seperti umur atau tanggal kelahiran informan.Sedangkan sumber data dalam penelitian ini yakni sumber data primer yang diperoleh melalui pengamatan dan wawancara dan sumber data sekunder dalam penelitian ini adalah terkait dengan dokumen atau catatan yang diambil Kantor Balai Desa Lolibu.

\section{Teknik Pengumpulan Data}

Teknik pengumpulan data yang digunakan dalam penelitian ini, yaitu dengan pengamatan terlibat (Participation Observation) dan wawancara mendalam (Indepth Interview) serta Studi Dokumen.

\section{PengamatanTerlibat (Participation Observation)}

Pengamatan yang dilakukan adalah pengamatan langsung, dimana peneliti turun langsung untuk mengamati masyarakat Desa Lolibu. Adapun yang diamati dalam penelitian ini adalah terkait harmonisasi sosial budaya antar umat beragama dan faktor-fakor yang menyebabkan terjadinya harmonisasi antar umat beragama di Desa Lolibu Kecamatan Lakudo Kabupaten Buton Tengah.

\section{Wawancara Mendalam (Indepth Interview)}

Wawancara dilakukan dengan mengadakan tatap muka secara lansung dengan informan yang disertai dengan tanyajawab yang dilakukan secara mendalam. Peneliti dapat menggali informasi seefisien dan semaksimal mungkin dari setiap informan terkait dengan harmonisasi sosial budaya antar umat beragama di Desa Lolibu Kecamatan Lakudo Kabupaten Buton Tengah. 


\section{Teknik Analisis Data}

Analisis data dilakukan secara deskriptif-kualitatif dengan menyusun satuan-satuan seluruh data yang dikumpul dari hasil pengamatan (Observasi) dan wawancara (Interview) serta dikumpulkan sesuai dengan golongannya, kemudian dilakukan analisis reduksi untuk mengevaluasi data yang kurang relevan, membuat abstraksi dan menyusun satuan-satuan data, melakukan kategorisasi data serta menyusun antar kategori data yang lainnya, sehingga dapat ditemukan makna dan kesimpulannya (Maleong, 2000: 190).

\section{HASIL DAN PEMBAHASAN \\ Harmonisasi Interaksi Sosial Budaya antar Umat Agama di Desa Lolibu Kecamatan Lakudo Kabupaten Buton Tengah}

Untuk mengetahui lebih jelasnya tentang keadaan harmonisasi sosial budaya antar umat beragama di Desa Lolibu Kecamatan Lakudo Kabupaten Buton Tengah yakni sebagai berikut:

\section{Adanya Ikatan Wilayah}

Ikatan wilayah menjadi salah satu terjadinya keharmonisan interaksi sosial budaya yang asosiatif antar Islam dan Kristen pada masyarakat Desa Lolibu Kecamatan Lakudo Kabupaten Buton Tengah, ikatan wilayah yang dimaksud adalah rasa cinta dan rasa memiliki (rasa nasionalisme) oleh setiap warga baik muslim maupun Kristen terhadap daerah Desa Lolibu, baik komunitas muslim maupun Kristen telah mendiami Desa tersebut sudah sejak lama, maka rasa memiliki tersebut menjadi penunjang utama terwujudnya keharmonisan rasa saling tolongmenolong dan menghargai tanpa mengedepankan agama mereka, potensi konflik-konflik yang dilatar belakangi oleh perbedaan keyakinan ini bisa diredam bahkan tidak bisa terjadi karena adanya ikatan wilayah tersebut.

\section{Saling Menghormati dan Menghargai Antar Penganut Agama}

Untuk

mengembangkan

kehidupan beragama, diperlukan suasana yang tertib, aman dan rukun. Ketentraman beribadat tidak mungkin terwujud dalam suasana yang tidak aman, di sana letak pentingnya yaitu kerukunan, ketertiban dan keamanan dalam kehidupan beragama. Masyarakat Desa Lolibu meciptakan suasana yang tertib, aman dan rukun dalam kehidupan beragama. Masyarakat selalu memupuk sikap saling menghormati dan menghargai antar umat beragama yang berbeda. Pada masyarakat Lolibu sikap saling menghormati dan menghargai dimaksud adalah yang menghargai orang yang sedang berpuasa, kebebasan dalam merayakan hari besar sesuai agama dan keyakinannya, tidak memaksakan kehendak untuk memeluk agama tertentu.Hal ini juga terlihat dari berbagai sikap atau prilaku yang mereka tanamkan seperti mengembangkan perbuatan-perbuatan terpuji yang mencerminkan sikap saling menghormati dan menghargai diantara sesama pemeluk agama. Mereka tidaklah memaksakan suatu agama kepada orang lain, hal ini disebabkan karena keyakinan beragama merupakan masalah pribadi yang menyangkut hubungan manusia dengan Tuhan yang mereka yakini.

\section{Harmonisasi Birokrasi Desa Lolibu} Interaksi sosial budaya merupakan hubungan-hubungan sosial dinamis yang menyangkut hubungan antar perseorangan, individu dengan kelompok, dan kelompok dengan 
kelompok lainnya sehingga dengan terciptanya interaksi sosial budaya, maka kermonisan selalu tercipta di tengah kehidupan mereka dari berbagai aktivitas mereka salah satunya birokrasi Desa lolibu, keberadaan agama Kristen dan Islam menjadi perhatian besar bagi pemerintah desa terutama dalam membangun komunikasi dengan tokohtokoh agama, pemuda dan adat demi terwujutnya pemerataan pembangunan yang dicita citakan bersama. Sebagai contoh misalnya keterwakilan semua golangan di pemerintahan desa dari Kristen dan Islam, pemerataan pembangunan yang bernuansa agama seperti tempat pengajian Al Quran, tempat belajar al kitab, bersinergi dengan BPD dalam membuat peraturan desa di tengah-tengah kehidupan mereka.

\section{Faktor-faktor Penyebab Terjadinya Harnonisasi Sosial Budaya}

Untuk mengetahui lebih jelasnya tentang faktor-faktor penyebab terjadinya harmonisasi sosial budaya antar umat beragama di Desa Lolibu Kecamatan Lakudo Kabupaten Buton Tengah yakni sebagai berikut:

\section{Kesatuan Adat dan Budaya}

Dengan adanya kehadiran kesatuan adat dan budaya di tengah dua pemuka agama yang ada di Desa Lolibu merupakan warisan kekayaanbudaya dalam menciptakan suatu keharmonisan masyarakat di antara mereka, sebab dengan kehadiran adat dan budaya inilah sampai masyarakat jarang sekali adanya konfik agama, walaupun isu nasional hadir konfil antara agama, namun mayarakat Desa Lolibu mereka tetap hidup rukun walaupun beda agama, salah satu bukti kekompakan toko adat adalah adanya warisan pemimpin adat yang setiap tahunya harus dipilih berdasarkan garis keturunan pemangku adat tersebut bukan berdasarkan agama tertentu. Secara kebetulan pemimpin adat tahun ini dari agama Kristen. Adapun adat dan budaya yang dimaksud diantaranya adalah, arung sesajen (kafolanto, ritual ini dilaksanakan pada seluruh unsur masyarakat Desa Lolibu adapun waktu pelaksanaanya dua tahun sekali sehingga dengan budaya inilah yang membuat pemersatu masyarakat Lolibu, tanpa melihat perbedaan agama, kemudian selain itu ada budaya pesta panen (tumbua) yang mana budaya ini dilaksanakan pada musim panen jagung sehingga dengan hal itulah masyarakat Desa Lolibu sangatlah menjunjung tinggi nilai adat dan budaya yang telah diwariskan oleh leluhur mereka sampai saat ini masih dilaksakan sebagai tumpuan utama dalam acuan dalam berinteraksi satu sama lain.

\section{Gotong Royong (Pohamba-hambai)}

Manusia adalah mahluk sosial yang tidak akan lepas dari ketergantungan pada orang lain. Sejak lahir manusia memerlukan bantuan dan membutuhkan kerjasamadengan orang lain, karena kondisi seperti itulah manusia harus melatih diri sejak dini untuk menjalin hubungan baik dengan orang lain dan bekerjasama dalam menyelesaikan suatu masalah atau pekerjaan. sejak dahulu masyarakat Desa Lolibu selalu menggunakan azas gotong royong yang bersifat kekeluargaan dalam setiap pekerjaan, terlihat bahwa gotong royong tersebut merupakan ciri khas budaya masyarakat Lolibu untuk selalu terjaling dalam interaksi dinatara mereka. Gotong royang yang dimaksud adalah pada tataran social seperti bersama sama dalam membersihkan kebun yang disebut (pokadulu),bersama 
sama dalam menanam jagung $($ hoa $)$, goto royong membangun rumah,membersikan pantai. Pada tataran keyakinan kembali pada agama masing-masing untuk saling bergotong royong misalnya pendanaan pembangunan mesjit atau gereja.

\section{Kawin Mawin}

Terciptanya keharmonisan umat beagama antara agama islam dan agama kristen yang ada di tengah kehidupan masyarakat Desa Lolibu Kecamatan Lakudo Kabupaten Buton Tengah, yang mana selain harmonisnya birokrasi pemerintahan, kesatuan adat dan budaya serta gotong royong, ternyata masih adayanglain yakni kawin mawin. Kawin mawin ternyata merupakan salah satu pendorong terciptanya keharmonisan antar umat beragama di Desa Lolibu, yang mana bagi masyarakat yang ada di desa tersebut ketika ia hendak menikahi salah seorang gadis misalnya mereka terkadang tanmpa mengenal stutus agama yang penting suka sama suka, antara calon suami dan calon istri, begitu pun juga halnya persoalan keluarga mereka, terkadang keluarga mengikuti kehendak kemauan anaknya mereka sendiri, dan kebiasaan tradisi ini terjadi sejak zaman dahulu di lakukan oleh keluarga mereka secara turun temurun,dengan pola yang sama dalam melaksanakan kawin mawin, dengan dibrikan kebebasana untuk memilih jodoh dan agama, maka perkawinan antar agama terjdi. Perkawinan ini mempersatukan kedua agamayaitu Islam dan Kristen, maka dengan itu terciptalah keharmonisan di tengah kehidupan mereka, karena di sebabkanoleh adannyahubungan darah (adik atau kaka) dalam perbedaan keyakinan, maka kerukunan keluarga didalam rumah tanggah sangatlah harmonis walaupun ia berbeda agama,tapi hal itu bagi mereka bukan ajang perpecahan tapi justru merupakan keragaman yang tetap dipelihara agar tetap terjadi keharmonisan ditengah masyarakat Desa Lolibu.

\section{KESIMPULAN}

Berdasarkan pembahasan di atas, maka kesimpulan dalam penelitian ini adalah sebagai berikut: Kerharnomisan interaksi sosial budaya antar umat beragamadi Desa Lolibu Kecamatan Lakudo Kabupaten Buton Tengah di antaranya yaitu: (1) adanya ikatan wilayah, (2) Saling menghormati dan menghargai dalam beribadah,dan(3) Harmonisasi birokrasi desa lolibu. Kemudian adapun foktor-faktor terjadinya interaksi sosial budaya antara umat beragama di antaranya yaitu: (1) Satuan adat dan budaya, (2) Gotong royong (Pohamba-hambai), dan kawin mawin.

\section{DAFTAR PUSTAKAN}

Hashemi Ak bar. 2017. Interaksi Antar Umat Beragama Studi Kasus Islam-KristenDi Kecamatan Sukakarya Kota Sabang. Skripsi Fakultas Ushuluddin dan Filsafat Prodi Studi Agama agama

Markarma. A (2014)dalam judul penelitianya Pola Interaksi Berbasis Agama Pada Masyarakat Rawan Konflik Di Kabupaten Sigi. ISTIQRA, Jurnal Penelitian Ilmiah, Vol. 2, No. 2 Juni-Desember 2014

Andhika, Rinchi Marry. 2014. Konflik Etnis antara Dayak dan Madura di Sampit dan Penyelesaiannya. FIB UI 
Carmin, Carluna Ixhi. 2018. Kerusuhan 10 Oktiber Tahun 1996

Situbondo. E-Journal Pendidikan Sejarah.Vol. 6. No. 1. Maret.

Gogali, L. 2009. Konflik Poso Suara Perempuan dan Anak Menuju Rekosiliasi Ingatan. Yogyakarta: Galangpress.

Haudy, Rusli. 2001. Tangisan Anak Pulau: Sebuah Catatan Tragedi Sampit. Jakarta: CV. DIharfin Jaya.

Lindawaty, Debora Sanur. 2011. Konflik Ambon: Kajian Terhadap Beberapa Akar Permasalahan dan Solusinya, Politica. Vol. 2. No. 2. November.

Moleong, J.L. 2000.Metode Penelitian Kualitatif.Bandung : Remaja Rosdakarya

Munajat, Clarisya. 2018. Dampak Konflik Agama. Diakses dari: http://www.academia.edu/32791 344/DAMPAK_KONFLIK_AG AMA. Diakses pada: 28 September 2018 pukul 14.19 WIB.

Rosyid, Moh. 2015. Mewujudkan Pendidikan Toleransi antarUmat Beragama diKudus: Belajar dari Komflik Tolikara Papua 1 Syawal 1436 H / 2015 $M$. Jurnal Pendidikan Islam, Quality. Vol. 3. No. 2.

2017. Peredam Konflik Agama: Studi Analisis Penyelesaian di Tolikara Papua 2015. Jurnal Afkaruna.Vol. 13. No. 1. Juni.
Ubad Badru Salam (2017) Interaksi Sosial Antar Umat Beragama Di Kecamatan Sukmajaya Depok (Studi atas Pandangan Tokoh Agama Islam dan Kristen). Studi Agama Agama Fakultas Ushuluddin Universitas Islam Negeri Syarif Hidayatullah Jakarta 